DOI: $10.21554 / \mathrm{hrr} .091807$

\title{
DIFFERENCES IN TACTILE PERCEPTION IN CHILDREN WITH AND WITHOUT VISUAL IMPAIRMENT
}

\author{
Dženana Radžo Alibegović, ${ }^{\text {a }}$ \\ Amela Teskeredžića \\ Aldijana Kudumović
}

\author{
Original scientific paper
}

Faculty of Education and Rehabilitation, University of Tuzla, $B \& H^{a}$

School for Education, Education and Rehabilitation of Persons with Difficulties in Psychophysical Development Zenica

Received: 17.7.2018

Accepted: 22.8.2018

\begin{abstract}
The aim of this study was to examine the differences in tactile perception in children with and without visual impairment. The study covered 30 examinees with visual impairment and 30 subjects without visual impairment aged 7-13, both sexes. The research was conducted in the "First Elementary School" ("Prva osnovna škola") in Zavidovici and the "Centre for Blind and Visually Impaired Children and Youth" Nedžarici - Sarajevo. The results of the study showed that children with visual impairment have a better developed tactile perception in their entirety, compared to children with no visual impairment, and that there is a statistically significant difference in the individual variables of tactile perception: "Two-Point Discrimination" (right), "Two-Point Discrimination R "(left) and" Stereognosis "(left).
\end{abstract}

Key words: tactile perception, children with visual impairment, children without visual impairment

\section{INTRODUCTION}

Perception or observation is the process by which we become conscious of objects, their properties and relationships through sensory organs. Although sensory content is always present in perception, it is influenced by attitudes and past experience, and is not a passive registration of stimuli that affect sensitive organs (Stančić, 1991). Explaining the role of perception in cognitive development, Montesori (2001) says that the senses are organs of capturing images of the outside world that are needed for intelligence, such as the arm of the body to capture the material things necessary to the body.
Visual impairment, especially blindness, is a difficult and complex disability, which conditions the development and putting into function of the remaining abilities, hearing, touch, smell, taste and high degree of mental concentration (Teskeredžić, 2005). Tactile perception is of great importance for blind children as a compensation mechanism for vision deficiency (Tulumović, 2013). Tactile perception has a great significance in acquainting the environment not only with people with visual impairments, but also with people without visual impairment. Depending on the information we want to get to know, we can use different parts of the body, especially the hand we can grab, lift, etc. (Mulahusic, 2017).

\footnotetext{
${ }^{1}$ Correspondence to:

Dženana Radžo Alibegović, Faculty of Education and Rehabilitation, University of Tuzla, Univerzitetska 1, 75000 Tuzla, B\&H

E-mail:dzenana.radzo@untz.ba
} 
Patients with visual impairment use a tactile and kinaesthetic input to learn about the environment they are in. Such an input should not be considered a "smaller sensation" that is used instead of vision, but should be viewed as another learning aid system (Cox and Dykes, 2001).

The processes of receiving, transmitting and processing tactile information rest on tactile abilities. Irregularities are transmitted to the back roots of the spinal cord or sensory cores of the cranial nerves. Furthermore, the importance of the spin-talamatic pathway and the system of medial lemniscussion, depending on the quality of the irritant, and the post-partial region of the parietal lobe. The processing of tactile sensations, or the process of perception (sequential analysis and integration into conscious forms), takes place in the secondary zones of various parts of the parietal lobe. These areas allow analysis of direction, strength, contacting localization, muscle movements and the like (Jablan, 2007).

According to Lukić (2007), it is important that the child learn to use his hands. The importance of wellorganized and skilful hand movements in a blind baby and practically blind children lies in the fact that the hand must be a substitute for vision (Radžo, 2008). Correct coordination, or coherent and rational finger and left-handed finger movements, can significantly facilitate and speed up the process of learning, reading and writing in children with visual impairment (Radžo Alibegović \& Begić, 2017).

The aim of this study was to evaluate the difference in tactile perception in children with and without visual impairment.

\section{RESEARCH METHODS}

\section{Sample respondents}

The sample of respondents consisted of children with visual impairment, elementary school age and children with no visual impairment, who, by age and gender, were equated with an experimental group.

The study covered a total of 60 respondents: 30 people with visual impairment, 30 subjects without visual impairment, aged 7-13, both sexes.

\section{Method of conducting research}

The research was conducted in the "First Elementary School" ("Prva osnovna škola") in Zavidovići and "Centre for Blind and Visually Impaired Children and Youth" Nedžarići - Sarajevo, with the prior consent of the parents whose children constituted the sample and the consent of the institutions in which the research was conducted. Children with visual impairment and children without visual impairment, as well as their parents, were previously familiar with the method of testing, where a detailed examination method was presented.

All respondents were examined individually in a separate room and a pleasant ambience.

\section{Measuring instrument}

Assessment of the development of tactile functions was examined using a clinical development scale from Luria-Nebraska for Children (LNNB-C). (Golden, 1987).

A scale for estimating tactile functions "C3" was used to estimate tactile functions. It contains 16 particles grouped in pairs (the same task is done with right and left hand).

\section{Data processing methods}

After the survey, the data obtained were processed by the computer statistical program SPSS 17.0 for the Microsoft Windows operating system. The basic statistical parameters were calculated: minimum and maximum results, arithmetic mean and standard deviation. To determine the significance of differences in the arithmetic mean of the observed variants of tactile perception between the two groups of subjects, a ttest for an independent sample at a significance level of $5 \%$ was used.

\section{RESULTS AND DISCUSSION}

\section{Results of descriptive statistics in relation to tactile perception of children without visual impairment}

Table 1 shows the measures of central tendency and dispersion measures in relation to individual variables of tactile perception in children without visual impairment. The arithmetic mean of the variable "Topognosia of the right" is .37 \pm .61 , median and modus 0 , while the minimum and maximum results range from $0-2$.

By inspecting the remaining individual tactile perception variables, it can be noted that the values of the arithmetic mean are less on the right-hand variables, except for the variable "Differentiation of tactile forearm sensations" where the values of the arithmetic meanings on the left and right sides are 0 . 
That is, on the mentioned variable, the respondents have an equally developed tactile perception on both the right and the left hand.

For a better understanding, it is necessary to note that according to the instructions of the author of the applied instrument, a 0 value denotes a normally developed function, 1 denotes a borderly developed func- tion, and value 2 denotes a pathologically developed function.

Such results are expected, taking into account that the majority of subjects without visual impairment are the dominant right arm, and therefore use it more and as such it more easily recognizes tactile sensations.

Table 1. Measures of central tendency and dispersion measures in relation to individual variables of tactile perception in children without visual impairment

\begin{tabular}{|c|c|c|c|c|c|c|c|}
\hline Variables & $\mathbf{M}$ & SE & MED & MOD & SD & MIN & MAX \\
\hline Topognosia $\mathrm{R}$ & 0.37 & 0.11 & 0.00 & 0.00 & 0.61 & 0.00 & 2.00 \\
\hline Topognosia L & 0.60 & 0.16 & 0.00 & 0.00 & 0.86 & 0.00 & 2.00 \\
\hline Sensitivity to pain $\mathrm{R}$ & 0.13 & 0.08 & 0.00 & 0.00 & 0.43 & 0.00 & 2.00 \\
\hline Sensitivity to pain L & 0.20 & 0.07 & 0.00 & 0.00 & 0.41 & 0.00 & 1.00 \\
\hline $\begin{array}{l}\text { Discrimination on the strength of } \\
\text { pressure R }\end{array}$ & 0.60 & 0.13 & 0.00 & 0.00 & 0.72 & 0.00 & 2.00 \\
\hline $\begin{array}{l}\text { Discrimination on the strength of } \\
\text { pressure L }\end{array}$ & 0.93 & 0.14 & 1.00 & 1.00 & 0.78 & 0.00 & 2.00 \\
\hline Two-Point Discrimination $\mathrm{R}$ & 0.77 & 0.13 & 1.00 & 1.00 & 0.73 & 0.00 & 2.00 \\
\hline Two-Point Discrimination L & 0.77 & 0.13 & 1.00 & 1.00 & 0.73 & 0.00 & 2.00 \\
\hline $\begin{array}{l}\text { Differentiation of tactile forearm } \\
\text { sensations R }\end{array}$ & 0.00 & 0.00 & 0.00 & 0.00 & 0.00 & 0.00 & 0.00 \\
\hline $\begin{array}{l}\text { Differentiation of tactile forearm } \\
\text { sensations L }\end{array}$ & 0.00 & 0.00 & 0.00 & 0.00 & 0.00 & 0.00 & 0.00 \\
\hline Graphesthesia R & 0.20 & 0.09 & 0.00 & 0.00 & 0.48 & 0.00 & 2.00 \\
\hline Graphesthesia L & 0.33 & 0.10 & 0.00 & 0.00 & 0.55 & 0.00 & 2.00 \\
\hline Graphesthesia numbers $\mathrm{R}$ & 0.17 & 0.08 & 0.00 & 0.00 & 0.46 & 0.00 & 2.00 \\
\hline Graphesthesia numbers L & 0.33 & 0.13 & 0.00 & 0.00 & 0.71 & 0.00 & 2.00 \\
\hline Stereognosis R & 0.20 & 0.07 & 0.00 & 0.00 & 0.41 & 0.00 & 1.00 \\
\hline Stereognosis L & 0.37 & 0.12 & 0.00 & 0.00 & 0.67 & 0.00 & 2.00 \\
\hline
\end{tabular}

Results of descriptive statistics in relation to tactile perception in children with visual impairment

Progress in sequential learning is similar to all senses. In children with visual impairment, more attention should be paid to the approach to pracing the task of presenting skills in smaller parts and advancement. Early research suggests that the development of tactile discrimination in children with visual impairment follows the model of using large to fine arm movements (whole hands to fingertips), from the earlier use of active touch to passive, from simpler to more complex. Recent research has provided more final information on tactile, kinaesthetic and haptic systems, and their effectiveness in making discrete differences and identifying objects and materials with different characteristics of Barrag and Erin (2001).

Studying twenty children with blindness in three levels from kindergarten to second grade, Kersh- man (1976) identified the following order in which this group acquired tactile skills:

1. Great solid geometric shapes

2. Flat figures (puzzles) less than geometric shapes

3. geometric figures with tactile dots less than flat figures

4. figures with tactile dots

5. Braille figures.

Heller $(1985,1989)$ concluded that people who never saw were equally successful in tactile perception, as did those who later healed, which led her to conclude that a visual experience was not necessary for tactile perception. Knowing Braille is not a guarantee for the correct representation of tactile images, although tactile skills and tactile perception experience have an impact. Earlier, she concluded that the simultaneous use of sight and touch by visually impaired people improved the recognition of tactile patterns; she suggested that people with high visual impairment use vision to conduct tactile research. 
Whether the results obtained from Table 2 are analysed, we can see that the arithmetic mean of the variable "Topognosia on the right" was $.33 \pm .66$, median and modus 0 , while the minimum and maximum results ranged from $0-2$. By inspecting the remaining individual variables of tactile perception, it can be noticed that the values of the arithmetic meanings are slightly lower on the right-hand variables, and these variables are „Sensitivity to pain“, „Discrimination on the strength of pressure“, ,Two-Point Discrimination“, „Graphesthesia“" „Graphesthesia numbers“ and „Stereognosis“.

From the above, it can be noticed that the tactile perception in children with visual impairment is proportionately developed on the right and left hand, because the differences between the arithmetic mean ranges between .05-.07. On the variable "Differentiation of tactile forearm sensations" there is a complete congruence in the development of tactile perceptions on the right and left hand, where the values of arithmetic meanings are 0 .
Similar results were also made by Radžo Alibegovic (2013), examining the development of tactile functions in subjects with visual impairment. To determine statistically significant differences among the observed variables, the t-test was used at a level of significance of $5 \%$. The results of the study also showed that there are no statistically significant differences between the arithmetic mean of the observed variants of tactile perception in subjects with visual impairment. $(p>, 05)$. The author came to the conclusion that tactile functions of the patients with visual impairment developed harmoniously on the right and left hand.

Jablan and Eskirović (2002) performed research on a sample of 35 girls and 60 boys with visual impairment and examined the quality of the development of tactile functions. It has been established that the tactile functions of pupils with vision impairment are harmoniously developed on the left and right hand, but that there is a lack of uniformity in the degree of complexity of the functions examined.

Table 2. Measures of central tendency and dispersion measures in relation to individual variables of tactile perception in children with visual impairment

\begin{tabular}{lccccccc}
\hline Variables & M & SE & MED & MOD & SD & MIN & MAX \\
\hline Topognosia R & 0.33 & 0.12 & 0.00 & 0.00 & 0.66 & 0.00 & 2.00 \\
Topognosia L & 0.47 & 0.13 & 0.00 & 0.00 & 0.73 & 0.00 & 2.00 \\
Sensitivity to pain R & 0.20 & 0.10 & 0.00 & 0.00 & 0.55 & 0.00 & 2.00 \\
Sensitivity to pain L & 0.13 & 0.08 & 0.00 & 0.00 & 0.43 & 0.00 & 2.00 \\
Discrimination on the strength of & & & & & & & \\
pressure R & 0.20 & 0.09 & 0.00 & 0.00 & 0.48 & 0.00 & 2.00 \\
Discrimination on the strength of & & & & & & & \\
pressure L & 0.30 & 0.11 & 0.00 & 0.00 & 0.60 & 0.00 & 2.00 \\
Two-Point Discrimination R & 0.53 & 0.11 & 0.00 & 0.00 & 0.63 & 0.00 & 2.00 \\
Two-Point Discrimination L & 0.60 & 0.13 & 0.00 & 0.00 & 0.72 & 0.00 & 2.00 \\
Differentiation of tactile forearm & & & & & & & \\
sensations R & 0.00 & 0.00 & 0.00 & 0.00 & 0.00 & 0.00 & 0.00 \\
Differentiation of tactile forearm & & & & & & & \\
sensations L & 0.00 & 0.00 & 0.00 & 0.00 & 0.00 & 0.00 & 0.00 \\
Graphesthesia R & 0.27 & 0.08 & 0.00 & 0.00 & 0.45 & 0.00 & 1.00 \\
Graphesthesia L & 0.23 & 0.08 & 0.00 & 0.00 & 0.43 & 0.00 & 1.00 \\
Graphesthesia numbers R & 0.27 & 0.12 & 0.00 & 0.00 & 0.64 & 0.00 & 2.00 \\
Graphesthesia numbers L & 0.57 & 0.16 & 0.00 & 0.00 & 0.90 & 0.00 & 2.00 \\
Stereognosis R & 0.07 & 0.05 & 0.00 & 0.00 & 0.25 & 0.00 & 1.00 \\
Stereognosis L & 0.10 & 0.06 & 0.00 & 0.00 & 0.31 & 0.00 & 1.00 \\
\hline
\end{tabular}

Determination of differences in individual variables of tactile perception among children with and without visual impairment

Table 3 shows the results of the t-test in relation to the development of individual variables of tactile perceptions and the observed group of subjects. Based on the obtained t-test results shown in Table 3, it can be concluded that there is a statistically significant difference in the three observed tactile perception variables. These variables are "Two-Point Discrimination Right", "Two-Point Discrimination Left", and the variable "Stereognosia Left". 
Table 3. Differences in the development of tactile perceptions in relation to visual impairment

\begin{tabular}{|c|c|c|c|c|c|}
\hline Variables & Visual impairment & $\mathbf{M}$ & SD & $\mathbf{t}$ & $p$ \\
\hline \multirow{2}{*}{ Topognosia R } & With & 0.33 & 0.66 & \multirow{2}{*}{-0.20} & \multirow{2}{*}{0.84} \\
\hline & Without & 0.37 & 0.61 & & \\
\hline \multirow{2}{*}{ Topognosia L } & With & 0.47 & 0.73 & \multirow{2}{*}{-0.64} & \multirow{2}{*}{0.519} \\
\hline & Without & 0.60 & 0.86 & & \\
\hline \multirow{2}{*}{ Sensitivity to pain $\mathrm{R}$} & With & 0.20 & 0.55 & \multirow{2}{*}{0.52} & \multirow{2}{*}{0.605} \\
\hline & Without & 0.13 & 0.43 & & \\
\hline \multirow{2}{*}{ Sensitivity to pain L } & With & 0.13 & 0.43 & \multirow[t]{2}{*}{-0.61} & \multirow[t]{2}{*}{0.542} \\
\hline & Without & 0.20 & 0.41 & & \\
\hline \multirow{2}{*}{$\begin{array}{l}\text { Discrimination on the strength of } \\
\text { pressure } R\end{array}$} & With & 0.53 & 0.63 & \multirow{2}{*}{-1.32} & \multirow{2}{*}{0.189} \\
\hline & Without & 0.77 & 0.73 & & \\
\hline \multirow{2}{*}{$\begin{array}{l}\text { Discrimination on the strength of } \\
\text { pressure L }\end{array}$} & With & 0.60 & 0.72 & \multirow{2}{*}{-0.88} & \multirow{2}{*}{0.378} \\
\hline & Without & 0.77 & 0.73 & & \\
\hline \multirow{2}{*}{ Two-Point Discrimination R } & With & 0.20 & 0.48 & \multirow{2}{*}{-2.51} & \multirow{2}{*}{0.015} \\
\hline & Without & 0.60 & 0.72 & & \\
\hline \multirow{2}{*}{ Two-Point Discrimination L } & With & 0.30 & 0.60 & \multirow[t]{2}{*}{-3.52} & \multirow[t]{2}{*}{0.001} \\
\hline & Without & 0.93 & 0.78 & & \\
\hline \multirow{2}{*}{ Graphesthesia R } & With & 0.27 & 0.45 & \multirow[t]{2}{*}{0.55} & \multirow[t]{2}{*}{0.583} \\
\hline & Without & 0.20 & 0.48 & & \\
\hline \multirow{2}{*}{ Graphesthesia L } & With & 0.23 & 0.43 & \multirow[t]{2}{*}{-0.78} & \multirow[t]{2}{*}{0.434} \\
\hline & Without & 0.33 & 0.55 & & \\
\hline \multirow{2}{*}{ Graphesthesia Numbers R } & With & 0.27 & 0.64 & \multirow{2}{*}{0.69} & 0.49 \\
\hline & Without & 0.17 & 0.46 & & \\
\hline & With & 0.57 & 0.90 & 1.11 & 0.269 \\
\hline Graphesthesia Numbers L & Without & 0.33 & 0.71 & & \\
\hline Stereoonosis $\mathrm{R}$ & With & 0.07 & 0.25 & -1.52 & 0.133 \\
\hline Stereognosis R & Without & 0.20 & 0.41 & & \\
\hline Sterenongic I & With & 0.10 & 0.31 & -1.98 & 0.052 \\
\hline Stereognosis L & Without & 0.37 & 0.67 & & \\
\hline
\end{tabular}

In other words, the obtained t-test results show that at the level of statistical significance of .01 and .05 patients with visual impairment achieve better results on the variables " Two-Point Discrimination Right" and " Two-Point Discrimination Left " in relation to subjects without visual impairment.

Also, subjects with visual impairment at the level of statistical significance of .05 achieve better results on the variable "Stereognosia left" compared to those with no visual impairment. From the obtained results in Table 3, it can be noticed that the patients with visual impairment achieved better results on other rightand-left variables, but that these differences were not statistically significant. Tactile discrimination is the ability to distinguish two simultaneous tactile irritations. Tactile discrimination is very pronounced on the fingertips, and considerably less on the palm skin, soles and the back. It depends on the density of tactile receptors in the skin, as well as on the size of the rep- resentation of these parts of the body in the sensitive zone of the brain.

Tactile discrimination is considered to be a group of fine, epicritical, superficial sensibility, with which we distinguish the object's touch and the localization of touch and is very important in the perception of the form. The respondents were asked to tell the examiner whether they felt one or two ends of the measuring instrument in contact with their finger, and to recognize and notice the difference in the alternating touch of the finger with 1 or 2 touches, where the distance between the two points was 0 to $.5 \mathrm{~mm}$.

It is known that people with visual impairment read the Braille letter with their fingertips and have fingers more sensitive to tactile stimuli than children without visual impairment. Also, people with visual impairment use daily tactile perception as compensation for vision and the daily dependence on touch sensation improves tactile sensitivity. 
It is therefore understandable that subjects with visual impairment achieved statistically significantly better results than subjects without visual impairment on the variables of the ability of stereognosis, i.e. tactile recognition of well-known objects without the involvement of the senses and the distinction of touch (Twopoint discrimination) at the tips of the finger.

Radžo Alibegović (2013) examined the sample of 70 respondents (35 with visual impairment and 35 without visual impairment) by examining the differences between the development of tactile functions between subjects with visual impairment and subjects without visual impairment. It was found that there are statistically significant variations in variables: Topognosia R, Topognosia L, Two-Point Discrimination R, TwoPoint Discrimination L and Stereognosis L.

\section{CONCLUSION}

Based on the results of the conducted research it can be concluded that:

- Children with visual impairment have a better developed tactile perception in their entirety, compared to children without visual impairment.

- There is a statistically significant difference in individual variants of tactile perception among children with and without visual impairment on variables: „Two-Point Discrimination R, „Two-Point Discrimination $\mathrm{L}$ and „Stereognosis $\mathrm{L}$ “.

- The findings obtained by this study can be useful for working with children with visual impairment, as they point to the need to exercise tactile perception, and especially in those areas where children with visual impairment have shown the greatest lagging behind.

- On the basis of the obtained results, appropriate exercises of tactile perception can be determined, behind each individual child, which could help in the selection of methods and principles of working with children with visual impairment.

\section{REFERENCES}

Barraga, N. i Erin, J.N. (2001). Visual Impairments and Learning. Austin, Texas: Pro-ed.

Cox, P.R., Dykes, M.K. (2001). Effective classroom adaptations for students with visual impairments. Teaching Exceptional Children, 33,6, 68-74.

Golden, J.C. (1987). Luria-Nebraska Neuropsychological Battery. Children's Revision, Manual. Los Angeles: Western Psychological services.

Heller, M.A (1985). Tactual perception of embossed Morse code and braille: The alliance of vision and touch. Perception 14: 563- 570 .

Heller, M. A. (1989). Texture perception in sighted and blind observers. Perception and Psychophysics, 45, 49-54.

Jablan, B. (2007). Motorne i taktilne funkcije kod slepe dece. Fakultet za specijalnu edukaciju i rehabilitaciju, CID, Beograd.

Jablan, B. i Eškirović, B. (2002). Taktilna i vizuelna efikasnost učenika sa oštećenjem vida. Nastava $i$ vaspitanje 3: 208219.

Lukić, A. (2007). Učenik s oštećenjem vida u redovitoj školi. Zagreb: Hrvatski savez slijepih.

Montesori, M. (2001). Otkriće deteta, Čigoja, Beograd.

Mulahusić, A. (2017). Razvijenost taktilne percepcije kod djece oštećenog vida. Magistarski rad. Edukacijsko-rehabilitacijski fakultet, Univerziteta u Tuzli.

Radžo, Dž. (2008). Psihomotorika djece oštećenog vida. Magistarski rad. Edukacijsko-rehabilitacijski fakultet, Univerziteta u Tuzli.

Radžo Alibegović, DŽ. (2013). Uticaj motoričkih i taktilnih funkcija na orijentaciju i mobilitet kod djece oštećenog vida. Doktorska disertacija. Edukacijsko-rehabilitacijski fakultet, Univerziteta u Tuzli.

Radžo Alibegović. Dž., Begić, H. (2017). Motoric speed and manual dexterity of children with impaired vision, Human Research in Rehabilitation, Volume 7, Issue 1.

Stančić, V. (1991). Oštećenja vida-biopsihosocijalni aspekti. Zagreb: Školska knjiga.

Teskeredžić, A. (2005). Stavovi socijalne sredine prema osobama oštećena vida. Magistarski rad. Edukacijko- rehabilitacijski fakultet Univerziteta u Tuzli, Tuzla.

Tulumović, Š. (2013). Usmena i pismena komunikacija djece sa oštećenjem vida. Tuzla: Off-set. 